\title{
The Brexit negotiations: If anywhere, where are we heading? "It is complicated"
}

\author{
Daniel Stockemer ${ }^{1}$
}

Published online: 21 June 2018

(C) European Consortium for Political Research 2018

\section{Introduction}

What does the British vote to leave the Europen Union (EU) mean and where are the negotiations heading? These are the main questions I discussed with prominent Europeanists during the ECPR General Conference annual EPS debate on September 8,2017 . The word that stuck with me the most in these discussions was "it is complicated." As of March 2018, nothing has changed in this complexity. The three contributions to this symposium by Sofia Vasilopoulou, Thomas Koenig and Richard Bellamy highlight some aspects of this complexity. First, Prof. Vasilopoulou illustrates that the situation on the British Islands is complicated because the political class and the public opinion have not made up their minds about determining the type of breakup they want. Prof. Koenig highlights that analyzing the Brexit negotiations is complicated because mainstream international relations theories, such as intergovernmentalism, do not allow us to analyze the Brexit negotiations. Prof Bellamy discusses the complexity of holding a second referendum. In this introductory piece, I will contextualize this complexity using the famous Facebook status "it is complicated" as an analogy. I will also embed some of my own opinions with regard to the Brexit negotiations within this opening piece.

\section{The EU-UK relationship: a relationship mired with distrust}

To indicate their relationship status to others, Facebook members can choose from the following options-in a relationship, engaged, married, it is complicated, in

Daniel Stockemer

daniel.stockemer@uottawa.ca

1 Ottawa University, Ottawa, ON, Canada 
an open relationship, widowed, separated, divorced and in a civil union. The label "it is complicated" is the most ambiguous label. It can signify two things: it can either mean that a couple is in a limbo state between "friends" and "in a relationship" or indicate dissatisfaction with an existing relationship. The relationship between the EU and Great Britain fits this label as it has never been a "waltz of joy between two embracing lovers" (CNN 2017). Throughout their relationship, romance and love never developed between the two partners. From the onset, Britain's relationship with the EU was mired with problems and distrust. It started out with two rejections, in 1961 and 1967, when French president Charles De Gaulle vetoed Great Britain's proposal to join, what was then called, the European Economic Community (EEC). It was not until 1973, when the UK solicited a relationship for the third time, that the EEC finally said yes. The thread that sealed the relationship was economics. ${ }^{1}$ By joining the ECC, Britain could access the European Market and the West European countries had access to the British market. As long as the union remained an economic union, the relationship between the two partners was characterized by financial struggles. For example, in 1975, just 2 years after successfully sealing their (rational) relationship, a faction of the Labor Party initiated a referendum on leaving the EEC, because it thought that Britain's contribution to the EU was too expensive. While this attempt of an early breakup was rather comfortably rejected by popular vote (67.5 percent of the population voted for remain), more financial struggles characterized the 1970s and 1980s. The most notable of these struggles was Prime Minister Thatcher's successful attempt to reduce Britain's annual contribution to the EEC budget. "I want my money back," she insisted and received a rebate from Brussels in 1985 (Wall 2008). Officially, the rebate was a compensation for the fact that Great Britain did not benefit from the Common Agricultural Policy as much as other countries. Unofficially, this rebate triggered lots of animosity, in particularly, in France (George 1998).

Mainly because of these financial struggles, Britain's relationship with the EU remained a platonic one throughout the 1970s and 1980s. Yet, we know from human experience that platonic relationships do not work well, particularly if one partner wants more and the other partner is torn between a common identity and breakup. Moving toward the EU, or an ever-growing political union, Britain's European partners wanted to become more intertwined and develop a common European identity. In the 1990s and 2000s, they advanced the European project featuring a single currency, a single European space characterized by the free movement of goods, services and people, as well as the strengthening of the EU institutions, in particular the European Parliament.

Across party lines, political elites in the UK have been uneasy about this European project. To cite the BBC (2014) "Europe has been a toxic issue in British politics." Politicians of all colors have constantly flip-flopped, one day embracing a stronger relationship with the EU, the other day threatening to breakup. To give a

\footnotetext{
1 To highlight, the UK's GDP per capita was around 30 percent larger in 1950 than the average of Germany, France, Luxembourg, Belgium, Italy and the Netherlands. However, in 1973 it was 10 percent below these EEC countries (Campus and Coricelli 2015).
} 
few examples, Mrs. Thatcher signed the Single European Act in 1986, the blueprint treaty to create a single currency and the single European Market, while just months later giving staunchly anti-European speeches (Daily Telegraph 2013). In 1990, Britain signed the European Exchange Rate Mechanism, only to withdraw 2 years later out of fear to the see British Pound crashing. In 1997, the country signed the Social Charter and considered joining the Euro just to see these plans fail because of opposition from its Chancellor Steven Brown and the Tories.

In the 2000s, Britain's relationship with the EU became more strenuous. Dissatisfaction with the hybrid status-Britain is an EU member, but has joined neither the Euro nor Schengen-has become more palpable both in Britain and on the continent. Confronted with growing Euroscepticism in his Conservative Party, then Prime Minister David Cameron set the Brexit vote in motion, when he vetoed the EU budget in 2011. This move left Great Britain more isolated than ever on the European stage. In addition, it allowed populist forces at the right and the far right at home to rally against two pillars of the European project: (1) the EU's founding ambition to forge an ever closer union and (2) the free movement of goods, people and services. ${ }^{2}$ This discomfort enticed David Cameron to promise a referendum vote, in case he would win the general elections in 2015, on whether Great Britain should stay or leave the Union. He won by a landslide. Yet, this landslide came with a price, he was forced to deliver on his campaign promise and hold a referendum. He did so, after negotiating a compromise with the EU on several key British demands aimed at strengthening British sovereignty and regulating the migrant flow into the EU. Yet, an increasingly alienated EU only met these demands half-way.

\section{The Brexit and Post-Brexit environment}

On June 23, 2016, 52\% of the British electorate voted in favor of leaving the EU. Yet, this vote did not lead to immediate separation of the two partners. A relationship of over 40 years, even if it is a platonic one, cannot be dissolved easily. According to the stipulation of Article 50 of the Treaty of the European Union, countries wishing to leave the EU have 2 years to negotiate the terms of leaving. Great Britain filed exit on March 29, 2017, which officially gave the country until March 29, 2019 to negotiate the divorce or rupture conditions. What appears an easy deadline on paper has proven difficult in praxis. In March 2018, 2 years after the Brexit vote, the Brits, regardless of whether we talk about the political class or the public, have not reconciled with the vote. The country remains deeply divided between those favoring a Brexit and those opposing it. In the population, lower educated individuals with lower social status who reside in the countryside are entrenched in the leave bloc, whereas more highly educated civic dwellers still favor to remain in the union (Skinner and Clemence 2016). In addition,

\footnotetext{
${ }^{2}$ In Britain, there has been growing discomfort with an ever increasing number of EU migrants in Britain, who according to populist rhetoric are a danger on the job market for Brits and milk the British social protection mechanisms.
} 
citizens on the British Isle have not reconciled the two contradictory positions. On the one hand, they do not want to bear the economic risks of leaving, while on the other hand, they want national sovereignty and immigration control (Matti and Zhou 2017).

The first contribution to the symposium by Sofia Vasilopoulou' and Liisa Talving contextualizes these contradictory positions. Using self-administered post-Brexit surveys, the two authors highlight that over 80 percent of the polled are in favor of continued access of British companies to the European market. At the same time, a majority also wants to have control over the country's borders. Vasilopoulou and Talving further highlight that the polled have double standards. In the majority, the surveyed think that they should have more benefits when working in the EU than EU citizens working on the British Islands. Clearly, this position is naïve, but it is also reflected in official statements. Prime Minister Theresa May, for example, favors an approach of what she labels managed divergence, which would mean sticking to some EU regulations, diverging moderately in others and opting for different solutions in a third group of regulations (Reuters 2018).

Thomas Koenig, in the second article, highlights that in an erratic environment where the partner who splits up does not know what they want, the major theory in international relations intergovernmentalism is a poor theoretical construct to explain the Brexit negotiations. He explains that the pillars of the theory-the socioeconomic foundation of national preferences, effective interstate bargains among governments in a complete information environment and institutional choices to transfer national sovereignty to the EU-can hardly explain the current Brexit process. Rather, he underscores that the Conservative Party, which is the unit of analysis relevant to determine the British position in the Brexit negations, is as divided as the country as a whole. Since they have no common position on Brexit, it remains an open question as to where the negotiations are heading.

In such a "complicated situation," wouldn't a second referendum be the solution? The author of the third short article, Richard Bellamy, is rather skeptical. For him, a possible second referendum could be problematic. While he agrees with proponents of a second referendum who might complain that the referendum question did not address the type of Brexit (i.e., hard or soft), criticize that the vote restricted EU citizens from participating and lament that the procedures did not allow 16-18 years to vote, he also concurs with opponents for whom the referendum was conducted under the laws of the country and reflected the will of the demos. Even if he favors a second referendum, Prof. Bellamy ends his article with the sober assessment that the time for a second referendum has passed.

For me, the second referendum remains a possibility because neither the political elites nor the public know what they want. They have not fully realized that you cannot have the cake and eat it too. Anybody who has gone through a breakup knows, at least in hindsight that you cannot breakup and keep all the benefits of the relationship while getting rid of the burdens. At some point in the near future, the political class and the public in Britain will have to realize that they cannot cherry pick. They will have to decide whether they want sovereignty and independence from the EU, or reap the benefits of the single market. Keeping both is pure delusion. If this realization comes, then everything is possible, a second referendum included. 


\section{How will the near future between the EU and Great Britain look like?}

Will there be a push to reverse course in Brexit? If not, what kind of Brexit will we have: a hard one or a soft one? How will the relations between Great Britain and the EU look if Britain leaves? 20 months after the Brexit vote, these questions remain as obscure as they were on the day of the Brexit vote nearly 2 years ago. Given the slow progress of the Brexit negotiations and the lack of a clear British position, it is more likely than not, that no agreement will be reached by March 29, 2019. In fact, it is hard to file for divorce or rupture if you have not made up your mind. And as long as the British position is not clear, nobody can predict the outcome of the "eventual breakup," nor can they say for certain if this breakup will ever happen. In the short run, the most probably scenario is that the two partners will prolong their relationship for a little longer, yet in a more asymmetrical fashion. Starting 2019, Britain will probably no longer be on the table in Brussels and Strasbourg, but the EU legal framework is still likely to apply until a deal is reached.

This implies that in the near future, Britain's relationship status with the EU will remain at "it is complicated." In other words, the UK is unlikely to switch its Facebook status to "separated" anytime soon and personally, I am not convinced this status will ever change.

\section{References}

BBC News. 2014. Britain and the EU: A long and rocky relationship, available at http://www.bbc.com/ news/uk-politics-26515129. Accessed 21 February 2018.

CNN. 2017. How Britain's complicated marriage to the EU was wrenched apart, available at https://www. cnn.com/2017/03/29/europe/article-50-robertson-analysis/index.html. Accessed 22 February 2018.

Campos, N., and F. Corricelli 2015. Why did Britain join the EU ? A new insight from economic history. Vox EU, February, available at https://voxeu.org/article/britain-s-eu-membership-newinsight-econo mic-history. Accessed 23 February 2018.

George, S. 1998. An awkward partner: Britain in the European Community. New York: Oxford University Press.

Matti, J., and J. Zhou. 2017. The political economy of Brexit: Explaining the vote. Applied Economics Letters 24(16): 1131-1134.

Reuters. 2018. After war cabinet, Britain's May to set out 'way forward' on Brexit, available at https:// ca.reuters.com/article/topNews/idCAKCN1G625U-OCATP. Accessed 23 February 2018.

Skinner, G., and M. Clemence. 2016. Economist/Ipsos Mori issues index. London: Ipsos Mori.

The Daily Telegraph. 2013 Margaret Thatcher: Conflict over Europe led to final battle. Available at http:// www.telegraph.co.uk/news/politics/margaret-thatcher/9980360/Margaret-ThatcherConflict-overEurope-led-to-final-battle.html. Accessed 22 February 2018.

Wall, S. 2008. A stranger in Europe: Britain and the EU from Thatcher to Blair. Oxford: Oxford University Press.

Daniel Stockemer is Associate Professor of Political Science in the School of Political Studies at the University of Ottawa and co-editor of European Political Science (EPS). His research interests are in political behavior and political representation. 